\title{
Selective Synthesis of Butene-1 Through Double-bond Migration of Butene-2 over $\eta$-Alumina Catalysts
}

\author{
Jong-Ki Jeon, Do Heui Kim, ${ }^{\dagger}$ and Young-Kwon Park, \\ Department of Chemical Engineering, Kongiu National University, Cheonan 331-717, Korea \\ ${ }^{\dagger}$ School of Chemical and Biological Engineering, Seoul National University, Seoul 151-744, Korea \\ \$School of Environmental Engineering, University of Seoul, Seoul 130-743, Korea. E-mail: catalica@uos.ac.kr \\ Received April 12, 2014, Accepted May 9, 2014
}

\begin{abstract}
Double bond migration of butene- 2 to butene- 1 over $\eta$-alumina was investigated. The effects of calcination temperature on catalytic properties were analyzed by applying BET surface area, $\mathrm{XRD}, \mathrm{NH}_{3}-\mathrm{TPD}$, and FT-IR of adsorbed pyridine techniques. The highest activity of the $\eta$-alumina catalyst calcined at $600{ }^{\circ} \mathrm{C}$ could be attributed not only to the highest amount of weak and medium strength acid sites, but also to the highest ratio of medium to weak strength Lewis acid sites.
\end{abstract}

Key Words : Butene-2, Double bond migration, $\eta$-Alumina catalyst, Butene-1, Acid sites

\section{Introduction}

$\mathrm{C}_{4}$ olefins are usually obtained as by-products during the production of ethylene in naphtha cracker. Gas feeds, especially ethane, are less costly than liquid feed, naphtha. Higher naphtha prices will lead the petrochemical industry to ethane cracking and potentially less $\mathrm{C}_{4}$ olefin productions, and eventually to shortage of butenes. Demand for butene-1, however, has been growing rapidly based on its use as a comonomer in the production of linear low density polyethylene and of a monomer for polybutene. ${ }^{1}$ If butene-2, currently used as a low-price fuel contained in $\mathrm{C}_{4}$ raffinate is isomerized, high value-added butene- 1 can be produced. ${ }^{1,2}$

Although researchers have attempted to carry out the isomerization of butene- 2 via double bond migration, the procedure has not been widely commercialized due to the fact that butene- 2 is thermodynamically more stable than butene-1 at lower temperatures. ${ }^{2-4}$ Because the most serious problems during the process of butene- 2 positional isomerization at higher temperatures are the transformation of butene-2 to isobutene, oligomerization to heavy elements and cracking to light elements, it is necessary to investigate a selective reaction for the production of butene-1., $5-10$

The majority of research on olefin isomerization has featured $\gamma$-alumina. ${ }^{11-13}$ Meanwhile, a few researchers have investigated $\eta$-alumina, which is inherently more acidic than $\gamma$-alumina. ${ }^{14}$ In our previous work, we found that the yield of butene-1 over $\eta$-alumina catalyst was higher than that over $\gamma$-alumina catalyst. ${ }^{15}$ Morterra and co-workers reported the presence of three Lewis acid sites associated with octahedral, tetrahedral-octahedral and tetrahedral cationic sites on $\eta$-alumina. ${ }^{16}$ Lundie and co-workers demonstrated that the surface structure of $\eta$-alumina had four kinds of Lewis acid sites such as weak, medium-weak, medium-strong and strong Lewis acid sites. ${ }^{14,17}$

Although it is well known that the high-temperature transition phases of alumina are less active than the low- temperature ones, there are some ambiguities concerning the influence of pretreatment temperature on the catalytic behavior over $\eta$-alumina catalyst. Walker et al. ${ }^{18}$ reported that increasing the calcination temperature of $\eta$-alumina in the range of $500-700{ }^{\circ} \mathrm{C}$ reduced the number of strong acid sites, although the number of medium strength sites increased. Because double bond isomerization of butene- 1 can be facilitated by weak acid sites rather than strong acid sites, the change in the distribution and the population of the acid sites of $\eta$-alumina with respect to the calcinations temperature is expected to affect the catalytic activity of the reaction over the catalyst.

Hence, the objective of the present study is to select the optimal condition for preparation of $\eta$-alumina catalyst for the double bond migration isomerization that converts butene- 2 to butene- 1 . The effects of calcination temperature on catalytic properties were analyzed through BET surface area, XRD, ammonia-temperature programmed desorption $\left(\mathrm{NH}_{3}-\mathrm{TPD}\right)$ and FT-IR of adsorbed pyridine.

\section{Experimental}

$\eta$-Alumina was prepared by mixing $200 \mathrm{~mol}$ of distilled water and $1 \mathrm{~mol}$ of alumina tri-sec-butoxide (ASB). ASB was put into a beaker containing refrigerated water with stirring and was aged for a day. After filtering and drying in the oven, it was calcined at a fixed temperature for $4 \mathrm{~h}$.

BET surface area of the catalyst was measured using an ASAP 2010 apparatus by Micromeritics. The crystallinity of the catalysts was examined by XRD analysis, which was carried out on a Rigaku D/MAX-II using $\mathrm{Cu} \mathrm{K} \alpha$ radiation energy.

$\mathrm{NH}_{3}$-TPD was performed in a Bel-Cat TPD apparatus. $0.02 \mathrm{~g}$ of sample was placed in a quartz tubular reactor and pretreated in a helium flow, heated to $400{ }^{\circ} \mathrm{C}$ at $10{ }^{\circ} \mathrm{C} / \mathrm{min}$, and kept for $2 \mathrm{~h}$. The sample was cooled to $100{ }^{\circ} \mathrm{C}$, and ammonia pulse was injected. After the physisorbed ammonia 
was purged with helium, the temperature was ramped to $550{ }^{\circ} \mathrm{C}$ at a rate of $10{ }^{\circ} \mathrm{C} / \mathrm{min}$.

FT-IR spectroscopy of adsorbed pyridine on the catalysts was done in a transmission IR cell. Self-supported wafers of the samples were subjected to a vacuum in the sample holder, followed by their activation at $350{ }^{\circ} \mathrm{C}$ for $1 \mathrm{~h}$. Pyridine vapor was admitted at room temperature until the catalyst surface was saturated. Pyridine was then desorbed until a pressure of $10^{-3}$ torr was reached. Infrared spectra were recorded using a Perkin-Elmer FT-IR PE2000 spectrometer fitted with an MCT detector.

The butene-2 $(99.3 \%$ ) with a ratio of $74($ cis $) / 26($ trans) was purchased from Aldrich. The butene- 2 isomerization reaction was performed using $0.13 \mathrm{~g}$ of the catalyst in a fixed bed reactor. The reaction temperature, pressure and the weight hourly space velocity (WHSV) range were $450{ }^{\circ} \mathrm{C}, 1 \mathrm{~atm}$ and $18-140 \mathrm{~h}^{-1}$, respectively. The product was analyzed using directly connected gas chromatography (Young Lin Acme 6000 GC).

\section{Results and Discussion}

Table 1 displays the BET surface areas of the catalysts calcined at different temperatures. The surface areas of the samples calcined below $400{ }^{\circ} \mathrm{C}$ remain around $620 \mathrm{~m}^{2} / \mathrm{g}$. Further calcination up to $800{ }^{\circ} \mathrm{C}$ gradually reduced the surface area to $183 \mathrm{~m}^{2} / \mathrm{g}$. XRD pattern of the sample calcined at 300 ${ }^{\circ} \mathrm{C}$ has not distinct characteristics of $\eta$-alumina (Figure 1 ). The XRD patterns with two diffraction peaks at $2 \theta$ values of 45.7 and 66.3 degrees confirmed that the catalysts calcined in the range of $400-700{ }^{\circ} \mathrm{C}$ contained $\eta$-alumina phase. ${ }^{19} \mathrm{On}$ further increasing the calcination temperature up to $800{ }^{\circ} \mathrm{C}$, a peak at $2 \theta$ value of 51.1 corresponding to $\theta$-alumina was observed, ${ }^{20}$ implying the phase transition from $\eta$ - to $\theta$ alumina started.

The effect of WHSV on double-bond migration of butene2 over $\eta$-alumina catalyst calcined at $600{ }^{\circ} \mathrm{C}$ was investigated (Figure 2). At the WHSV of $18 \mathrm{~h}^{-1}$, the conversion of butene-2 was $23.5 \%$ and butene-1 selectivity was $95.0 \%$. When the WHSV was increased to $70 \mathrm{~h}^{-1}$, butene- 2 conversion and butene-1 selectivity were not changed. A drastic decrease in butene-2 conversion was observed, however, when the WHSV was increased from 70 to $110 \mathrm{~h}^{-1}$. Further increase of WHSV to $140 \mathrm{~h}^{-1}$ reduced the conversion of butene- 2 to $10.6 \%$, while the selectivity to butene- 1 remain-

Table 1. BET surface area and ammonia consumption during TPD over $\eta$-alumina calcined at various temperatures

\begin{tabular}{ccc}
\hline $\begin{array}{c}\text { Calcination } \\
\text { temperature }\left({ }^{\circ} \mathrm{C}\right)\end{array}$ & $\begin{array}{c}\text { BET Surface area } \\
\left(\mathrm{m}^{2} / \mathrm{g}\right)\end{array}$ & $\begin{array}{c}\mathrm{NH}_{3} \text { consumption } \\
(\mathrm{mmol} / \mathrm{g})\end{array}$ \\
\hline 300 & 622 & - \\
400 & 623 & - \\
500 & 443 & $1.93 \times 10^{-1}$ \\
600 & 282 & $1.96 \times 10^{-1}$ \\
700 & 239 & $1.35 \times 10^{-1}$ \\
800 & 183 & $1.13 \times 10^{-1}$ \\
\hline
\end{tabular}

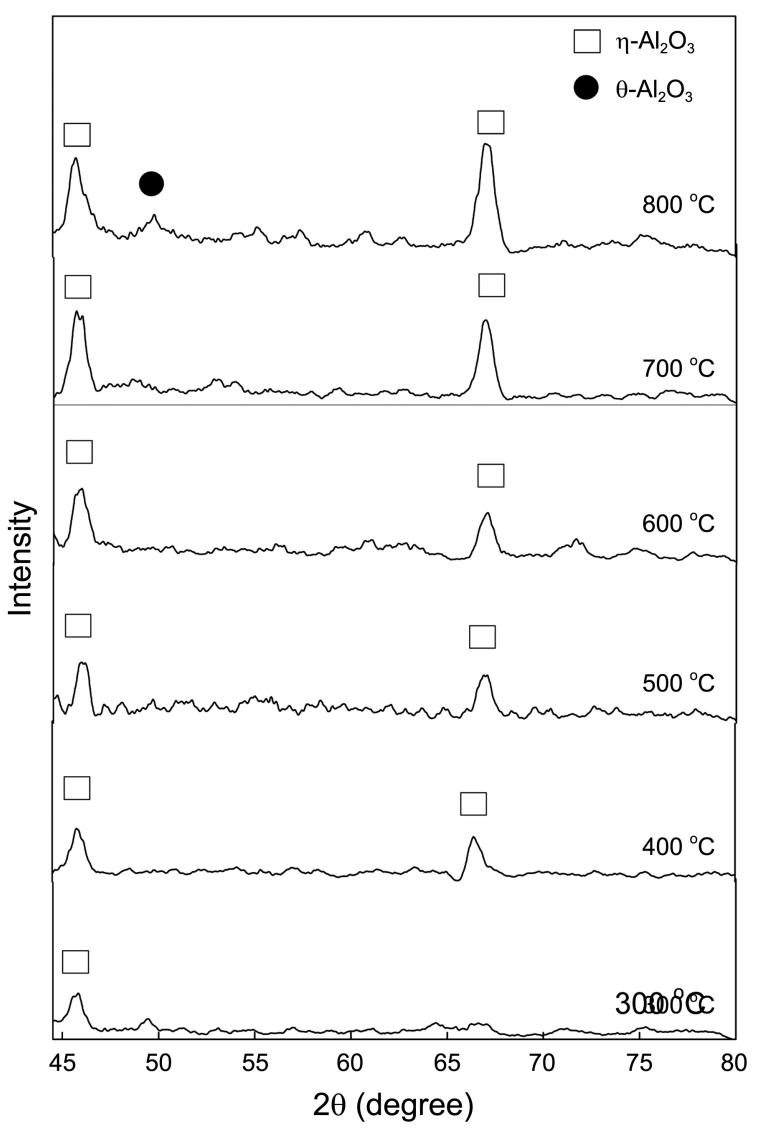

Figure 1. XRD patterns of $\eta$-alumina calcined at various temperatures.

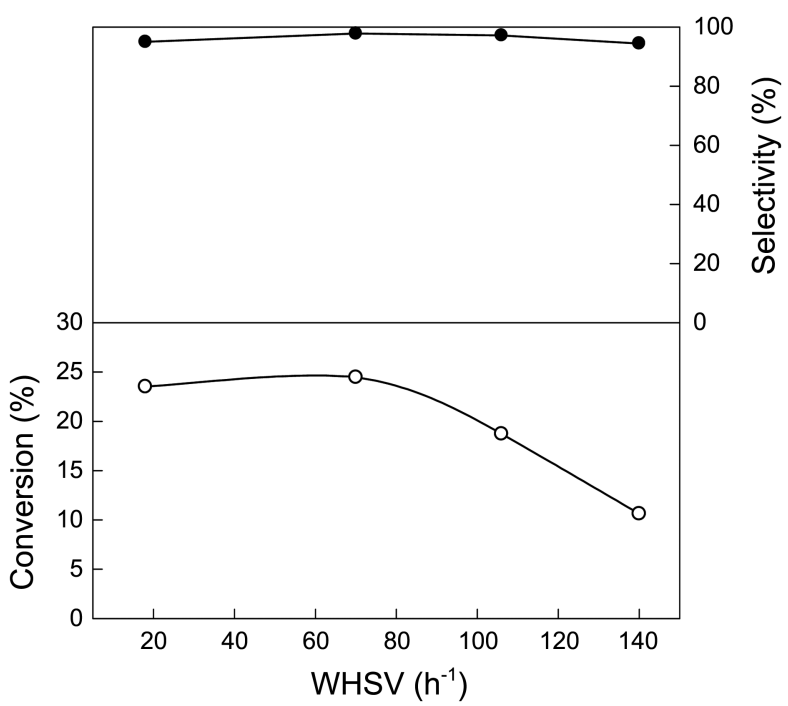

Figure 2. Effect of WHSV on conversion of butene- 2 and selectivity to butene- 1 over $\eta-\mathrm{Al}_{2} \mathrm{O}_{3}$ catalyst calcined at $600{ }^{\circ} \mathrm{C}$ (Reaction condition: $450{ }^{\circ} \mathrm{C}, 1 \mathrm{~atm}$ ).

ed over $94.0 \%$. Thermodynamic equilibrium of butene- 2 isomerization was calculated. ${ }^{4}$ The equilibrium mole of butene- 1 at $450{ }^{\circ} \mathrm{C}$ and $1 \mathrm{~atm}$ is $26.3 \%$. Therefore, butene- 2 conversions at lower WHSV, with values below $70 \mathrm{~h}^{-1}$, seem to be controlled by thermodynamic equilibrium between butenes. At higher space velocities, those over $110 \mathrm{~h}^{-1}$, 


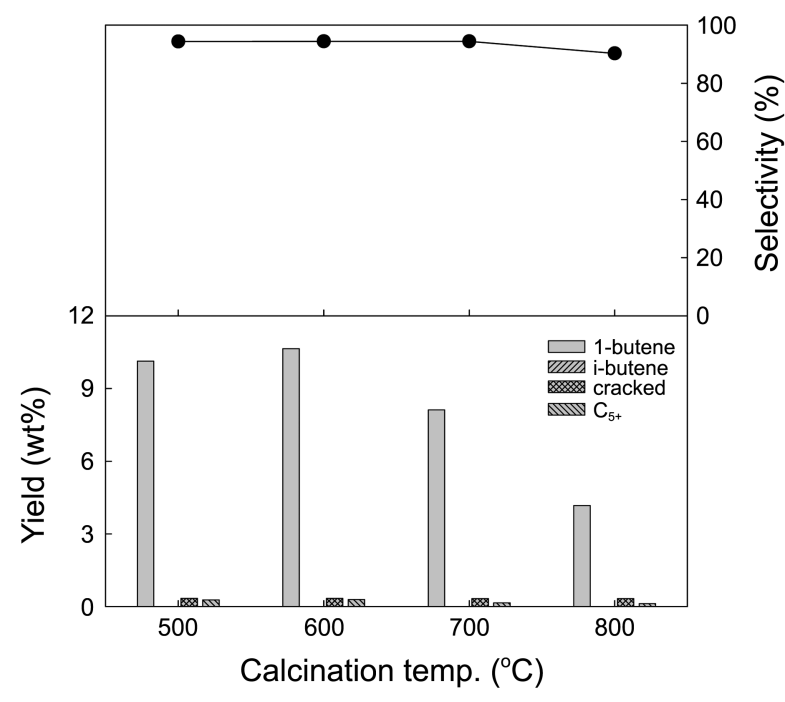

Figure 3. Yield and selectivity of butene-2 isomerization over $\eta$ $\mathrm{Al}_{2} \mathrm{O}_{3}$ catalysts calcined at various temperatures.

however, the conversion decreased with space velocity. The yield of butene-1 (10.4\%) at WHSV of $140 \mathrm{~h}^{-1}$ is far from its thermodynamic value. Because this observation suggests that there was a kinetically controlled reaction at higher WHSV, the catalytic performance of the catalysts in this study was investigated at WHSV of $140 \mathrm{~h}^{-1}$ thereafter. In addition, it was noted that butene- 2 hardly reacted without catalyst under the reaction conditions: $450{ }^{\circ} \mathrm{C}, 1 \mathrm{~atm}$.

Figure 3 shows the yields and product selectivity of butene-2 isomerization at time-on-stream of $2 \mathrm{~h}$ using $\eta$ alumina catalysts calcined at various temperatures. It was found that butene- 2 conversion was 10.2 and $10.4 \%$ at calcination temperatures of 500 and $600{ }^{\circ} \mathrm{C}$, respectively. Conversion decreased with increasing calcination temperature above $700{ }^{\circ} \mathrm{C}$ and was only $4.2 \%$ at a calcination temperature of $800{ }^{\circ} \mathrm{C}$. It was clearly shown that the selectivity of butene-1 remained over $90.0 \%$ and was not affected by calcination temperature in the temperature range studied. Because the surface areas of the $\eta$-alumina catalysts decreased drastically and monotonically with increasing calcination temperature in the range of $500-800{ }^{\circ} \mathrm{C}$, as shown in Table 1, the highest activity over the $\eta$-alumina catalyst calcined at $600{ }^{\circ} \mathrm{C}$ could not be explained by the surface area of the catalysts, therefore, we paid attention to the characteristics of surface acid sites over the catalysts.

$\mathrm{NH}_{3}$-TPD profiles and number of acid sites for five samples calcined at different temperatures are given in Figure 4 and Table 1, respectively. $\mathrm{NH}_{3}$-TPD for the sample calcined at $500{ }^{\circ} \mathrm{C}$ consisted of a broad peak around $170^{\circ} \mathrm{C}$ followed by an overlapping peak at $270{ }^{\circ} \mathrm{C}$. These peaks could be assigned as weak and medium strength acid sites, respectively. For the sample calcined at $600^{\circ} \mathrm{C}$, the number of acid sites increased slightly. In addition the peak temperature of the medium strength acid site increased to around $280^{\circ} \mathrm{C}$. Further increase of calcination temperature to $800{ }^{\circ} \mathrm{C}$ resulted in a decrease of the number of acid sites, even though the peak temperature of the medium strength acid site increased

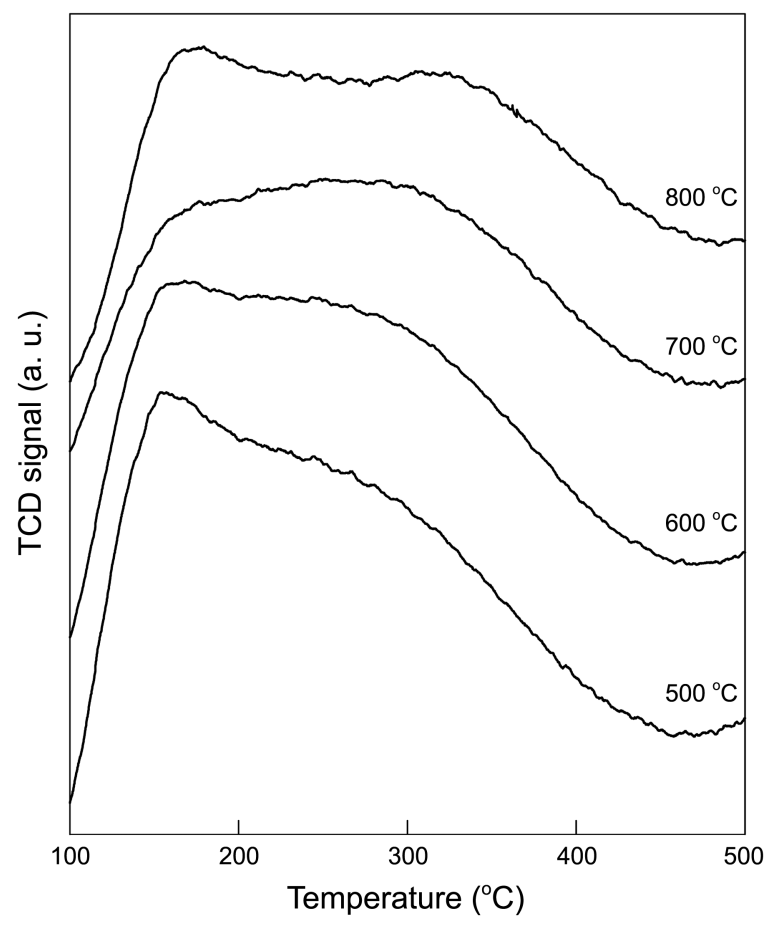

Figure 4. $\mathrm{NH}_{3}$-TPD profiles of $\eta$-alumina calcined at various temperatures.

to $310{ }^{\circ} \mathrm{C}$. Consequently, the sample calcined at $600{ }^{\circ} \mathrm{C}$ showed the highest number of acid sites, well corresponding to the activity results.

Figure 5 shows the FT-IR spectra of the pyridine adsorbed on the $\eta$-alumina calcined at $600{ }^{\circ} \mathrm{C}$, followed by the desorption at elevated temperatures from 25 to $300{ }^{\circ} \mathrm{C}$. The presence of four bands at $1623,1613,1592$ and $1578 \mathrm{~cm}^{-1}$ demonstrates four type of Lewis acid site..$^{14,17,21}$ At lower temperatures below $100{ }^{\circ} \mathrm{C}$, a band at $1592 \mathrm{~cm}^{-1}$ with a shoulder at $1578 \mathrm{~cm}^{-1}$ was dominant among the four bands.

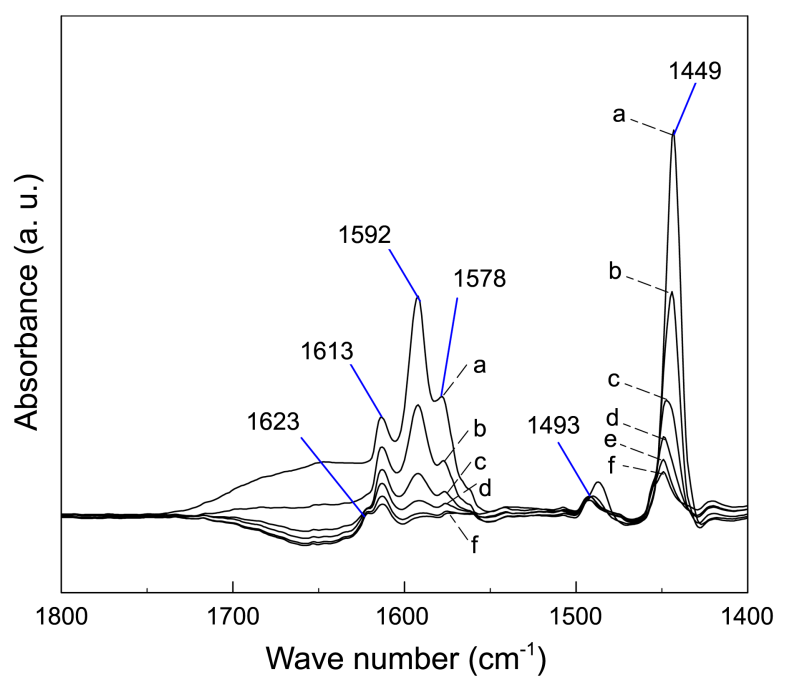

Figure 5. FTIR spectra of adsorbed pyridine over $\eta-\mathrm{Al}_{2} \mathrm{O}_{3}$ catalyst calcined at $600{ }^{\circ} \mathrm{C}$. The catalyst was desorbed under $10^{-3}$ torr at (a) 25 , (b) 100 , (c) 150 , (d) 200 , (e) 250 , and (e) $300{ }^{\circ} \mathrm{C}$. 


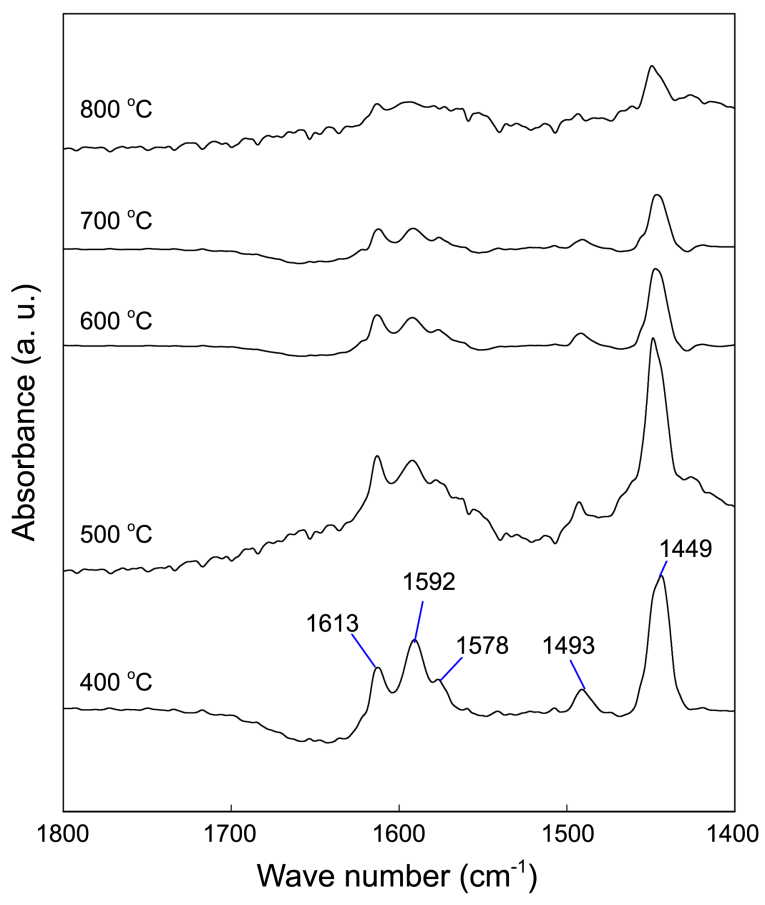

Figure 6. FTIR spectra of adsorbed pyridine on $\eta$-alumina calcined at various temperatures (measured at $150{ }^{\circ} \mathrm{C}$ and $10^{-3}$ torr).

An increase in the desorption temperature seems to reduce the intensity of the band at $1592 \mathrm{~cm}^{-1}$ more drastically than that of the band at $1613 \mathrm{~cm}^{-1}$. Finally, the band at $1613 \mathrm{~cm}^{-1}$ with a shoulder at $1623 \mathrm{~cm}^{-1}$ was dominant after desorption at $300{ }^{\circ} \mathrm{C}$. It is clear that the band at $1613 \mathrm{~cm}^{-1}$ shows the presence of a higher strength acid site than does the band at $1592 \mathrm{~cm}^{-1}$. These trends are consistent with those reported in the literature, and three bands at 1623,1613 , and $1592 \mathrm{~cm}^{-1}$ could be assigned to strong strength Lewis acid sites on tetrahedral aluminum vacancies, medium strength Lewis acid sites on tetrahedral aluminum vacancies and weak strength Lewis acid sites on octahedral aluminum, respectively. ${ }^{14,16}$

In order to obtain the distribution of acid sites on the $\eta$ alumina with as a function of calcination temperature, IR spectra of pyridine adsorption at $150{ }^{\circ} \mathrm{C}$ were recorded (Figure 6). For the $\eta$-alumina catalyst calcined at $400{ }^{\circ} \mathrm{C}$, a band at $1592 \mathrm{~cm}^{-1}$ assigned to weak strength Lewis acidic sites was dominant in the range of $1630-1560 \mathrm{~cm}^{-1}$. It is noticeable that the relative intensity of the band at $1613 \mathrm{~cm}^{-1}$ to that at $1592 \mathrm{~cm}^{-1}$ on the $\eta$-alumina catalyst calcined over $500{ }^{\circ} \mathrm{C}$ is much higher than that on that calcined at $400^{\circ} \mathrm{C}$. The intensity ratio of the band at $1613 \mathrm{~cm}^{-1}$ band to that at $1592 \mathrm{~cm}^{-1}$ was $0.76,1.04,1.10,0.98$, and 0.97 for the catalysts calcined at $400,500,600,700$ and $800^{\circ} \mathrm{C}$, respectively. It is apparent that the catalyst calcined at $600^{\circ} \mathrm{C}$ has the highest ratio of medium strength Lewis acid sites on tetrahedral aluminum vacancies to weak strength Lewis acid sites on octahedral aluminum. Therefore, upon summarizing the results of ammonia TPD and IR spectra of pyridine adsorption, the highest activity of the $\eta$-alumina catalyst calcined at $600{ }^{\circ} \mathrm{C}$ can be attributed not only to the highest number of weak and medium strength acid sites, but also to the higher ratio of medium strength Lewis acid sites to weak strength Lewis acid sites.

\section{Conclusion}

Although the surface areas of the $\eta$-alumina catalysts decreased drastically and monotonically with increasing calcination temperature in the range of $500-800{ }^{\circ} \mathrm{C}$, the $\eta-$ alumina catalyst calcined at $600{ }^{\circ} \mathrm{C}$ showed the highest activity in double-bond migration of butene-2. The activity behavior can be explained by not only the highest number of weak and medium strength acid sites, but also to the optimum ratio of medium to weak strength Lewis acid sites, based on the $\mathrm{NH}_{3} \mathrm{TPD}$ and the FTIR of pyridine adsorption results.

Acknowledgments. This research was supported by the Basic Science Research Program through the National Research Foundation of Korea (NRF) funded by the Ministry of Education, Science and Technology (2010-0023600).

\section{References}

1. Vora, B. V., United States Patent 6,005,150 to UOP LLC, 1999.

2. Pavlov, O. S.; Karsakov, S. A.; Pavlov, S. Y.; Russ. J. Appl. Chem. 2009, 82, 1117.

3. Moronta, A.; Luengo, J.; Ramírez, Y.; Quiñónez, González, J. E.; Sánchez, J. Appl. Clay Sci. 2005, 29, 117.

4. Jeon, J. K.; Lee, H.; Yim, J. H.; Kim, Y. S.; Lee, S. J.; Park, Y. K.; Shon, J. K.; Kim, J. M. Catal. Lett. 2007, 119, 179.

5. Mooiweer, H. H.; Jong, K. P.; Kraushaar-Czarnetzki, B.; Stork, W. H. J.; Krutzen, B. C. H. Stud. Surf. Sci. Catal. 1999, 84, 2327.

6. Coronati, I. L.; Font, G. M.; Fontana, N. E.; Querini, C. A.; Comelli, R. A. Catal. Today 2008, 63, 133.

7. Lee, S. H.; Shin, C. H.; Hong, S. B. J. Catal. 2004, 223, 200.

8. Lee, Y.; Park, M. B.; Kim, P. S.; Vicente, A.; Fernandez, C.; Nam, I. S.; Hong, S. B. ACS Catal. 2013, 3, 617.

9. Park, Y. K.; Kim, S. J.; You, N.; Cho, J.; Lee, S. J.; Lee, J. H.; Jeon, J. K. J. Ind. Eng. Chem. 2011, 17, 186.

10. You, N.; Yim, J. H.; Lee, S. J.; Lee, J. H.; Park, Y. K.; Jeon, J. K. J. Nanosci. Nanotechnol. 2007, 7, 3800.

11. Carre, S.; Gnep, N. S.; Revel, R.; Magnoux, P. Appl. Catal. A 2008, 348, 71

12. Bautista, F. M.; Campelo, J. M.; Garcia, A.; Luna, D.; Marinas, J. M.; Quiros, R. A.; Romero, A. A. Appl. Catal. A 2003, 243, 93.

13. Benitez, V. M.; Fígoli, N. S. Catal. Commun. 2002, 3, 487.

14. Lundie, D. T.; A. McInroy, R.; Marshall, R.; Winfield, J. M.; Jones, P.; Dudman, C. C.; Parker, S. F.; Mitchell, C.; Lennon, D. J. Phys. Chem. B 2005, 109, 11592.

15. Lee, K.; Jeon, J. K.; Hwang, E. H.; Ko, Y. S.; Park, Y. K.; Lee, S. J.; Lee, J. H. J. Ind. Eng. Chem. 2007, 13, 1062.

16. Morterraa, C.; Chiorino, A.; Ghiotti, G.; Garrone, E. J. Chem. Soc. Faraday Trans. 1979, 75, 271.

17. McInroy, A. R.; Lundie, D. T.; Winfield, J. M.; Dudman, C. C.; Jones, P.; Lennon, D. Langmuir 2005, 21, 11092.

18. Walker, G. S.; Pyke, D. R.; Werrett, C. R.; Williams, E.; Bhattacharya, A. K. Appl. Surf. Sci. 1999, 147, 228.

19. Santos, P. S.; Santos, H. S.; Toledo, S. P. Materials Research 2000, 3, 104.

20. Kwak, J. H.; Hu, J.; Lukaski, A.; Kim, D. H.; Szanyi, J.; Peden, C. H. F. J. Phys. Chem. C 2008, 112, 9486.

21. Liu, X.; Truitt, R. E. J. Am. Chem. Soc. 1997, 119, 9856. 